\title{
ANALISIS PENERAPAN SISTEM PENGENDALIAN INTERN TERHADAP KINERJA DAN PENERIMAAN RETRIBUSI PARKIR DI DINAS PERHUBUNGAN KOTA MANADO
}

\author{
Claudio V. Munaiseche ${ }^{1}$, Ventje Ilat ${ }^{2}$, Robert Lambey ${ }^{3}$ \\ ${ }^{1,2,3}$ Fakultas Ekonomi dan Bisnis, Jurusan Akuntansi, Universitas Sam Ratulangi, Jl. Kampus Bahu, Manado, \\ 95115, Indonesia
}

Email : claudiomunaiseche@gmail.com

\begin{abstract}
Internal control systems are needed for every government agency from planning, supervision, to accountability, must be carried out in an orderly, controlled, efficient and effective. So that the performance of government agencies is directed and reaches the goal. This study aims to determine whether the implementation of the internal control system on the performance and retribution parking income at the Manado city transportation office is adequate or inadequate. This research method is a qualitative descriptive study. Based on the results of the research and discussion, it can be seen that the internal control system on the performance and retribution parking income at Transportation department of at Manado city has been "adequate and effective" because the procedure for retribution parking income have elements of internal control, namely the proper delegation of authority and responsibility. the separation of functions, recording carried out accurately and on time, the documents used contain clear and reliable information and are carried out continuously. The target achievement of the 2016-2017 is effective and the performance had been in accordance with government regulation number 60 of 2008 concerning the government's internal control system.
\end{abstract}

Keywords: Government Internal Control System, Performance, Income Parking Retribution

\section{PENDAHULUAN}

Retribusi Daerah merupakan salah satu sumber pendapatan asli daerah yang memungkinkan untuk dikembangkan di daerah. Salah satu jasa/fasilitas tersebut yaitu Retribusi Parkir yang merupakan salah satu dari retribusi daerah yang dikelola oleh Dinas Perhubungan. Retribusi parkir ini menjadi sarana penting yang dimanfaatkan oleh masyarakat khususnya yang menggunakan kendaraan bermotor. Namun pengelolaan penerimaan retribusi parkir ini menjadi satu hal yang perlu diperhatikan oleh Dinas Perhubungan Kota Manado, karena sejak tahun 2016 realisasi penerimaan retribusi parkir ini mengalami penurunan yang signifikan dibandingkan penerimaan retribusi lainnya yang dikelola oleh Dinas Perhubungan Kota Manado. Maka dari itu sistem pengendalian intern (internal control) sangat dibutuhkan oleh Dinas Perhubungan Kota Manado, karena dengan adanya pengendalian intern maka segala kegiatan yang dilakukan oleh Dinas Perhubungan Kota Manado lebih terarah dan terhindar dari resiko kecurangan.

\section{TINJAUAN PUSTAKA}

Akuntansi Sektor Publik. Siregar (2015:1) menyatakan bahwa secara umum akuntansi dapat diartikan sebagai proses pengidentifikasian, pencatatan, pengukuran, pengklasifikasian, pengikhtisaran kejadian dan transaksi keuangan, serta penyajian hasilnya. Sektor publik adalah sektor yang mengelola dana masyarakat. Berdasarkan pengertian akuntansi dan pengertian sektor publik tersebut, maka akuntansi sektor publik menurut 
Siregar (2015:3) "merupakan aktivitas akuntansi yang dilakukan terhadap kejadian dan transaksi keuangan organisasi sektor publik".

Akuntansi Pemerintahan. Nordiawan (2012:4) menyatakan bahwa akuntansi pemerintahan mengkhususkan dalam pencatatan dan pelaporan transaksi-transaksi yang terjadi pada badan pemerintahan. Akuntansi pemerintahan adalah pengaplikasian akuntansi di bidang keuangan pemerintahan yang khususnya pada tahapan pencatatan, pelaporan, dan pelaksanaan anggaran termasuk segala pengaruh yang ditimbulkannya pada suatu tingkat atau unit pemerintahan, baik itu bersifat sementara atau pun permanen.

Sistem Pengendalian Intern. COSO (2013:3) mendefinisikan pengendalian internal merupakan proses, yang dipengaruhi oleh dewan direksi entitas, manajemen, dan personel lainnya, yang dirancang untuk memberikan jaminan yang memadai terkait pencapaian tujuan yang berkaitan dengan operasi, pelaporan, dan kepatuhan. Elemen Sistem Pengendalian Intern dalam Peraturan Pemerintah Republik Indonesia Nomor 60 Tahun 2008 terdiri atas lima unsur, yaitu Lingkungan Pengendalian; Penilaian Resiko; Kegiatan pengendalian; Informasi dan Komunikasi; Pemantauan.

Kinerja. Mahsun (2014:25) menyatakan bahwa kinerja (performance) merupakan gambaran mengenai tingkat pencapaian pelaksanaan suatu kegiatan atau program atau kebijakan dalam mewujudkan sasaran, tujuan, misi dan visi organisasi yang tertuang dalam strategi planning suatu organisasi. Pengukuran kinerja merupakan suatu proses penilaian kemajuan pekerjaan terhadap tujuan dan sasaran yang telah ditentukan sebelumnya.

Sistem Penerimaan Kas. Sujarweni (2015:96) menyatakan bahwa sistem penerimaan kas merupakan suatu prosedur catatan yang dibuat untuk melaksanakan kegiatan penerimaan uang yang berasal dari berbagai macam sumber.

Retribusi Daerah. Mardiasmo (2013:15) mendefinisikan bahwa "Retribusi merupakan pungutan daerah sebagai pembayaran atas jasa atau perizinan tertentu yang khusus disediakan dan/ atau diberikan oleh pemerintah daerah untuk kepentingan orang pribadi atau badan.

Retribusi Tempat Khusus Parkir. Retribusi tempat khusus parkir termasuk dalam jenis retribusi jasa usaha. Pelayanan tempat khusus parkir adalah pelayanan penyediaan tempat parkir khusus disediakan, dimiliki, dan/atau dikelola oleh pemerintah daerah, tidak termasuk yang disediakan dan dikelola oleh badan usaha milik daerah dan pihak swasta. Menurut Peraturan Daerah Kota Manado Nomor 4 tahun 2011 Retribusi tempat khusus parkir, selanjutnya disebut retribusi adalah pembayaran atas jasa pelayanan tempat khusus parkir yang disediakan, dimiliki, dan/atau dikelola oleh pemerintah kota Manado. Parkir adalah keadaan tidak bergerak suatu kendaraan yang tidak bersifat sementara.

Retribusi Parkir Tepi Jalan Umum. Retribusi parkir tepi jalan umum merupakan retribusi jasa umum. Menurut Peraturan Daerah Kota Manado Nomor 3 Tahun 2011 Retribusi pelayanan parkir di tepi jalan umum, selanjutnya disebut Retribusi adalah pembayaran atas jasa pelayanan penyediaan pelayanan parkir di tepi jalan umum yang ditentukan oleh pemerintah daerah sesuai dengan ketentuan peraturan perundang-undangan.

\section{METODE PENELITIAN}

Jenis Penelitian. Penelitian ini menggunakan jenis penelitian deskriptif Kualitatif. Penelitian deskriptif kualitatif merupakan penelitian yang berusaha mendeskripsikan dan menginterpretasikan sesuatu, misalnya kondisi atau hubungan yang ada, pendapat yang berkembang, proses yang sedang berlangsung, akibat atau efek yang terjadi, atau tentang kecenderungan yang tengah berlangsung.

Tempat dan Waktu Penelitian. Tempat penelitian ini dilakukan pada Dinas Perhubungan Pemerintah Kota Manado, Alamat Jln. Sungai Barito Tuminting. Waktu Penelitian laksanakan pada bulan Mei 2018 sampai selesai. 
Prosedur Penelitian. Prosedur penelitian merupakan serangkaian kegiatan yang dilaksanakan oleh seorang peneliti secara teratur dan sistematis untuk mencapai tujuan-tujuan penelitian tersebut. Oleh karena itu peneliti menyusun langkah-langkah yang dilakukan dalam pelaksanaan penelitian pada Dinas Perhubungan Pemerintah Kota Manado yaitu sebagai berikut:

1. Peneliti mengajukan permohonan penelitian melalui surat penelitian pada Dinas Perhubungan Kota Manado.

2. Pimpinan Dinas Perhubungan Kota Manado menyetujui kemudian membuat surat disposisi pimpinan.

3. Peneliti melakukan penelitian dengan mengumpulkan data-data yang diperlukan.

4. Peneliti melakukan analisis data penelitian dan pembahasan penelitian.

5. Kemudian peneliti menarik kesimpulan dan memberikan saran.

Metode Pengumpulan Data. Pengumpulan data dilakukan untuk memperoleh informasi yang dibutuhkan dalam rangka mencapai tujuan penelitian. Dalam metode pengumpulan data, peneliti harus menentukan terlebih dahulu jenis data, sumber data dan teknik apa yang digunakan dalam pengumpulan data tersebut.

Jenis Data. Jenis data dalam penelitian ini adalah data kualitatif. Data kualitatif yang dibutuhkan dalam penelitian ini adalah sistem pengendalian intern pemerintah dan penerimaan retribusi parkir di Dinas Perhubungan Kota Manado.

Sumber Data. Sumber data yang digunakan dalam penelitian ini adalah data primer dan data sekunder. Data primer yang dibutuhkan merupakan data olahan dan diperoleh langsung dari Dinas Perhubungan Kota Manado, dan data sekunder merupakan data yang diambil dari bahan pustaka.

Teknik Pengumpulan Data. Dalam melengkapi hasil penelitian ini, maka penulis melakukan pengumpulan data dengan cara melakukan wawancara terhadap pimpinan Dinas Perhubungan Kota Manado, pengamatan lewat jasa internet, serta di perpustakaan, buku dan sumber-sumber lain yang relevan dengan data yang dibutuhkan.

Instrument Penelitian. Instrument yang digunakan dalam penelitian ini yaitu dengan menggunakan 5 indikator SPIP berdasarkan peraturan pemerintah nomor 60 tahun 2008 tentang sistem pengendalian intern pemerintah, sebagai berikut: Lingkungan Pengendalian, Penilaian Resiko, Kegiatan Pengendalian, Informasi dan Komunikasi, dan Pemantauan.

Metode Analisis. Metode analisis dalam penelitian ini adalah metode deskriptif. Penggunaan metode analisis deskriptif bertujuan untuk mendapatkan gambaran yang lebih jelas dan terperinci mengenai suatu keadaan berdasarkan dari data atau informasi yang didapatkan. Tahap-tahap analisis data dalam penelitian ini adalah sebagai berikut:

a. Melakukan perbandingan antara Sistem Pengendalian Intern Pemerintah Nomor 60 Tahun 2008 dengan Sistem Pengendalian Intern yang ada dalam Dinas Perhubungan Kota Manado yang dilakukan dengan cara wawancara berdasarkan 5 indikator SPIP yaitu Lingkungan Pengendalian; Penilaian Resiko; Kegiatan Pengendalian; Informasi dan Komunikasi; Pemantauan yang diaplikasikan menggunakan skala Guttman. Skala Guttman adalah skala yang digunakan untuk memberikan jawaban yang bersifat jelas (tegas) dan konsisten, misalnya, yakin-tidak yakin, ya-tidak, benar-salah, positif-negatif, pernah-belum pernah, setuju-tidak setuju dan sebagainya (Sudaryono $2015: 64$ ).

b. Menguji Sistem Pengendalian Intern dalam melaksanakan sistem dan prosedur penerimaan retribusi parkir.

c. Menguji efektifitas sistem pengendalian internal pada penerimaan retribusi yang dikelola Dinas Perhubungan Kota Manado. 


\section{HASIL PENELITIAN DAN PEMBAHASAN}

\subsection{Hasil Penelitian}

Penerapan Sistem Pengendalian Intern Pada Kinerja Dinas Perhubungan Kota

Manado. Wawancara atas pengendalian intern ini mendasarkan pada Peraturan Pemerintah Republik Indonesia Nomor 60 Tahun 2008 tentang Sistem Pengenalian Intern Pemerintah (SPIP). Hasil pengujian SPIP meliputi 5 unsur sebagai berikut:

a. Lingkungan Pengendalian

1. Menyelenggarakan pelatihan dan pembimbingan teknis pada masing-masing bidang untuk meningkatkan kompetensi pegawai dalam melaksanakan pekerjaan.

2. Telah menerapkan performance based management atau manajemen berbasis kinerja untuk mengukur kinerja pegawai lalu dibandingkan dengan target organisasi.

3. Pegawai telah memiliki kompetensi yang formal dan sertifikat sesuai dengan bidangnya.

4. Pegawai telah memahami wewenang dan tanggung jawab yang diterimanya.

5. Menyelenggarakan pelatihan dan pembimbingan teknis administrasi keuangan untuk meningkatkan kompetensi pegawai.

6. Memiliki perencanaan (target).

b. Penilaian Resiko

1. Pimpinan telah membuat rencana kerja atas penerimaan tiap tahun anggaran.

2. Telah mengidentifikasi faktor resiko eksternal dan internal dalam pengelolaan retribusi dan langkah penanganan dampak dari resiko.

c. Kegiatan Pengendalian

1. Melakukan reviu atas kinerja intstansi pada tingkat kegiatan.

2. Memiliki prosedur untuk memastikan bahwa setiap pegawai memiliki kompetensi dibidangnya.

3. Adanya pemisahan fungsi dalam kegiatan seluruh transaksi atas penerimaan retribusi.

4. Transaksi dan kejadian dicatat dengan segera dan didokumentasikan dalam rangka mengendalikan kegiatan dan menjadi dasar pengambilan keputusan.

5. Terdapat pengendalian fisik atas barang kuasi (dokumen bernilai uang).

6. Memiliki prosedur operasi standar pengelolaan kegiatan yang dibiayai dari pendapatan (contoh upah pungut).

d. Informasi dan Komunikasi

1. Menyampaikan informasi besarnya target penerimaan Dishub kepada kepala daerah dan dinas terkait secara tepat waktu.

2. Menyampaikan informasi dari sumber internal dan eksternal kepada pimpinan Dishub sebagai bahan pelaporan atas pencapaian kinerja.

3. Mengirimkan laporan keuangan kepada dinas keuangan tepat waktu.

4. Mengirim semua laporan yang diwajibkan kepada masing-masing UPT kepada dinas teknis terkait dan ke dinas pendapatan.

e. Pemantauan

1. Pimpinan telah melakukan monitoring secara berkelanjutan dan pengujian secara berkala atas kinerja instansinya.

2. Inspektorat pemerintah telah melakukan pemeriksaan atas pengelolaan penerimaan Dishub Manado.

3. Rapat digunakan untuk membahas penerapan sistem pengendalian intern terhadap kinerja Dishub.

4. Melakukan langkah-langkah perbaikan sebagai tindak lanjut atas penyempurnaan yang dilakukan oleh aparat pengawasan intern pemerintah 


\section{Prosedur Penerimaan Retribusi Parkir}

Tabel 1. Prosedur Penerimaan Retribusi Parkir Tepi Jalan Umum

\begin{tabular}{|c|c|c|c|}
\hline Langkah & $\begin{array}{c}\text { Aktivitas } \\
\end{array}$ & Pelaksana & Output \\
\hline 1 & $\begin{array}{l}\text { Menggunakan Tepi jalan Umum untuk Parkir } \\
\text { Kendaraan }\end{array}$ & Masyarakat & $\begin{array}{l}\text { Parkir di tepi jalan } \\
\text { umum }\end{array}$ \\
\hline 2 & $\begin{array}{l}\text { Memberikan karcis parkir TJU sesuai dengan } \\
\text { jenis kendaraan }\end{array}$ & $\begin{array}{l}\text { Petugas lapangan } \\
\text { (Buruh) }\end{array}$ & $\begin{array}{l}\text { Karcis dan Uang } \\
\text { setoran }\end{array}$ \\
\hline 3 & $\begin{array}{l}\text { Mengambil dan mencatat uang parkir dari } \\
\text { petugas lapangan serta memberikan dan } \\
\text { melaporkan hasil setoran ke KTU }\end{array}$ & $\begin{array}{l}\text { Penagih (Petugas } \\
\text { Dishub) }\end{array}$ & $\begin{array}{lrr}\text { Rekapan } & \text { Jumlah } \\
\text { Karcis dan } & \text { Uang } \\
\text { Setoran } & & \end{array}$ \\
\hline 4 & $\begin{array}{l}\text { Menerima, mencatat dan menyetor ke } \\
\text { Bendahara Penerimaan }\end{array}$ & $\begin{array}{lr}\text { Kepala Bagian } \\
\text { Tata Usaha (KTU) }\end{array}$ & $\begin{array}{lr}\text { Uang Setoran dan } \\
\text { Rekapan } \\
\text { Setoran }\end{array}$ \\
\hline 5 & $\begin{array}{l}\text { Menerima, menghitung, mencatat dan membuat } \\
\text { STS ( Surat Tanda Setoran ) }\end{array}$ & $\begin{array}{l}\text { Bendahara } \\
\text { Penerimaan }\end{array}$ & Uang Setoran \\
\hline 6 & $\begin{array}{l}\text { Memverifikasi STS yang telah dibuat oleh } \\
\text { Bendahara Penerimaan }\end{array}$ & $\begin{array}{l}\text { Kasubag } \\
\text { Keuangan }\end{array}$ & $\begin{array}{l}\text { Paraf Surat Tan } \\
\text { Setoran (STS) }\end{array}$ \\
\hline 7 & $\begin{array}{l}\text { Mengetahui dan menandatangani STS yang } \\
\text { akan disetor ke Bank }\end{array}$ & Kepala Dinas & $\begin{array}{l}\text { Tanda Tangan Surat } \\
\text { Tanda Setoran (STS) }\end{array}$ \\
\hline 8 & $\begin{array}{l}\text { Menerima STS dan menyetor uang retribusi ke } \\
\text { Bank (Kas Daerah). }\end{array}$ & $\begin{array}{l}\text { Bendahara } \\
\text { Penerimaan }\end{array}$ & $\begin{array}{l}\text { Bukti Setoran Bank } \\
\text { dan } \\
\text { capaian PAD }\end{array}$ \\
\hline
\end{tabular}

Sumber: Data Olahan dari Dinas Perhubungan Kota Manado Sub Bagian Program, Keuangan Evaluasi dan Pelaporan

Tabel 2. Prosedur Penerimaan Retribusi Parkir Khusus

\begin{tabular}{|c|c|c|c|}
\hline Langkah & Aktivitas & Pelaksana & Output \\
\hline 1 & Melewati / masuk pos parkir & Masyarakat & Karcis \\
\hline 2 & $\begin{array}{l}\text { Memberikan karcis dan menerima uang kepada } \\
\text { / dari kendaraan yang melewati pos parkir }\end{array}$ & Petugas Jalur & Uang Setoran \\
\hline 3 & $\begin{array}{l}\text { Di setiap pos parkir menerima, mengatur, } \\
\text { menghitung dan mencatat uang setoran }\end{array}$ & Kasir & $\begin{array}{lr}\text { Rekapan Jumlah } \\
\text { Karcis dan Uang } \\
\text { Setoran }\end{array}$ \\
\hline 4 & $\begin{array}{l}\text { Mengambil dan mencatat setoran dari setiap } \\
\text { pos tagihan parkir serta memberikan dan } \\
\text { melaporkan hasil setoran ke KTU }\end{array}$ & $\begin{array}{l}\text { Penagih (Petugas } \\
\text { Dishub) }\end{array}$ & $\begin{array}{lr}\text { Rekapan } & \text { Jumlah } \\
\text { Karcis dan } & \text { Uang } \\
\text { Setoran } & \end{array}$ \\
\hline 5 & $\begin{array}{l}\text { Menerima, mencatat dan menyetor ke } \\
\text { Bendahara Penerimaan }\end{array}$ & $\begin{array}{l}\text { Kepala } \\
\text { Tata } \\
\text { (KTU) }\end{array}$ & $\begin{array}{l}\text { Uang Setoran dan } \\
\text { Rekapan Uang } \\
\text { Setoran }\end{array}$ \\
\hline 6 & $\begin{array}{l}\text { Menerima, menghitung, mencatat dan } \\
\text { membuat STS ( Surat Tanda Setoran ) }\end{array}$ & $\begin{array}{l}\text { Bendahara } \\
\text { Penerimaan }\end{array}$ & Uang Setoran \\
\hline 7 & $\begin{array}{l}\text { Memverifikasi STS yang telah dibuat oleh } \\
\text { Bendahara Penerimaan }\end{array}$ & $\begin{array}{l}\text { Kasubag } \\
\text { Keuangan }\end{array}$ & $\begin{array}{l}\text { Paraf Surat Tanda } \\
\text { Setoran (STS) }\end{array}$ \\
\hline 8 & $\begin{array}{l}\text { Mengetahui dan menandatangani STS yang } \\
\text { akan disetor ke Bank }\end{array}$ & Kepala Dinas & Tanda Tangan STS \\
\hline 9 & $\begin{array}{l}\text { Menerima STS dan menyetor uang retribusi ke } \\
\text { Bank (Kas Daerah). }\end{array}$ & $\begin{array}{l}\text { Bendahara } \\
\text { Penerimaan }\end{array}$ & $\begin{array}{l}\text { Bukti } \text { Setoran Bank } \\
\text { dan Perolehan } \\
\text { capaian PAD }\end{array}$ \\
\hline
\end{tabular}

Sumber: Data Olahan dari Dinas Perhubungan Kota Manado Sub Bagian Program, Keuangan Evaluasi dan Pelaporan 


\section{Target dan Realisasi Penerimaan Dinas Perhubungan Kota Manado}

Tabel 3. Target dan Realisasi Penerimaan Dinas Perhubungan Kota Manado Tahun 2016-2017

\begin{tabular}{|c|c|c|c|c|c|c|c|}
\hline \multirow[t]{2}{*}{ No } & \multirow{2}{*}{$\begin{array}{c}\text { Tahun } \\
\text { Jenis } \\
\text { Penerimaan }\end{array}$} & \multicolumn{3}{|c|}{2016} & \multicolumn{3}{|c|}{2017} \\
\hline & & $\begin{array}{c}\text { Target } \\
\text { (Rp) }\end{array}$ & $\begin{array}{c}\text { Realisasi } \\
(\mathbf{R p})\end{array}$ & $\%$ & $\begin{array}{c}\text { Target } \\
\text { (Rp) }\end{array}$ & $\begin{array}{l}\text { Realisasi } \\
\text { (Rp) }\end{array}$ & $\%$ \\
\hline 1 & $\begin{array}{l}\text { Ret. Parkir } \\
\text { Tepi Jalan } \\
\text { Umum }\end{array}$ & $134,965,000$ & $108,525,000$ & 80.41 & $262,872,000$ & $216,140,000$ & 82.22 \\
\hline 2 & $\begin{array}{l}\text { Ret. } \\
\text { Pengujian } \\
\text { Kendaraan } \\
\text { Bermotor }\end{array}$ & $1,344,169,567$ & $1,565,604,900$ & 116.47 & $1,401,060,000$ & $1,474,506,100$ & 105.24 \\
\hline 3 & $\begin{array}{l}\text { Ret. } \\
\text { Terminal } \\
\text { Bulanan }\end{array}$ & $758,764,000$ & $735,045,000$ & 96.87 & $753,712,000$ & $669,228,000$ & 88.79 \\
\hline 4 & $\begin{array}{l}\text { Ret. Parkir } \\
\text { Khusus }\end{array}$ & $129,986,000$ & $98,123,000$ & 75.49 & $41,484,000$ & $18,035,000$ & 43.47 \\
\hline 5 & $\begin{array}{l}\text { Ret. } \\
\text { Trayek }\end{array} \quad$ Ijin & $159,375,000$ & $96,750,000$ & 60.71 & $250,500,000$ & $289,500,000$ & 115.57 \\
\hline 6 & $\begin{array}{l}\text { Ret. } \\
\text { Kepelabuhan }\end{array}$ & $7,374,000$ & $7,871,000$ & 106.74 & $15,372,000$ & $27,783,000$ & 180.74 \\
\hline & Jumlah & $2,539,633,567$ & $2,611,918,900$ & 102.85 & $2,725,000,000$ & $2,695,192,100$ & 98.91 \\
\hline
\end{tabular}

\subsection{Pembahasan}

Analisis Penerapan Sistem Pengendalian Intern Pemerintah Pada Kinerja Dinas

Perhubungan Kota Manado. Berdasarkan hasil penelitian maka Dinas Perhubungan Kota Manado sudah mencerminkan adanya penerapan 5 unsur SPIP yaitu sebagai berikut:

1. Lingkungan Pengendalian. Lingkungan pengendalian pada Dinas Perhubungan Kota Manado telah memadai guna mendorong dipatuhinya kebijakan manajemen dalam menjalankan organisasi secara efektif dan efisien. Namun masih ditemukan kelemahan yaitu pegawai Dinas Perhubungan Kota Manado belum diwajibkan menandatangani pakta integritas dan aturan perilaku dan beberapa realisasi penerimaan retribusi yang dikelola Dinas Perhubungan Kota Manado tahun 2017 belum mencapai target yaitu; Retribusi parkir tepi jalan umum sebesar $82,22 \%$, Retribusi terminal bulanan sebesar $88,79 \%$, dan Retribusi parkir khusus sebesar 43,47\%.

2. Penilaian Resiko. Pelaksanaan penilaian resiko oleh Dinas Perhubungan Kota Manado telah memadai guna mencapai tujuan organisasi. Hal ini tercermin telah optimalnya daya guna baik dari sumber daya manusia, sistem informasi, telah optimalnya rencana kerja atas penerimaan retribusi, telah mengidentifikasi factor internal dan eksternal dalam pengeloaan retribusi sehingga resiko penyimpangan dapat diantisipasi. Namun masih ditemukan kelemahan yaitu Belum terselenggaranya penilaian resiko secara rutin dengan ditandai belum tersusunnya Fraud Plan Control sebagai bentuk rencana pengendalian terhadap penyimpangan penerimaan dan belum terbentuknya satgas SPIP yang aktif, belum tersusunnya pemetaan atas potensi penerimaan retribusi.

3. Kegiatan Pengendalian. Kegiatan pengendalian pada Dinas Perhubungan Kota Manado guna mencapai tujuan yang meliputi kebijakan, prosedur, teknik dan mekanisme telah memadai. Hal ini tercermin dari adanya pemisahan tugas yang cukup diberbagai bidang sesuai dengan kompetensi yang dimilikinya, pencatatan yang akurat dan tepat waktu atas transaksi dan kejadian, adanya pengendalian fisik atas asset, pimpinan telah melakukan review atas kinerja instansinya, akuntabilitas terhadap sumber daya dan pencacatannya, pelatihan dan pembimbingan sumber daya manusia. 
4. Informasi dan Komunikasi. Sistem informasi dan komunikasi pada Dinas Perhubungan Kota Manado telah memadai guna mencapai tujuan dalam hal menyediakan, memanfaatkan, mengelola dan memperbarui sistem informasi secara terus menerus.

5. Pemantauan. Pemantauan yang dilakukan oleh Dinas Perhubungan Kota Manado telah memadai guna mencapai tujuan mendeteksi kemungkinan adanya penyimpangan dalam penerimaan retribusi yang merupakan factor resiko yang dapat merugikan Dinas Perhubungan Kota Manado.

Dari 27 pertanyaan yang diajukan terdapat 22 atau 81,48\% jawaban "ya" dan 5 atau 18,51\% jawaban "tidak". Maka dapat disimpulkan jawaban ya berada pada tingkat $80 \%-90 \%$ sehingga pengendalian intern pada kinerja dikategorikan "Cukup Efektif".

Analisis Penerapan Sistem Pengendalian Intern Atas Prosedur Penerimaan

Retribusi Parkir. Analisis penerapan sistem pengendalian intern atas penerimaan retribusi parkir dalam penelitian ini berfokus pada evaluasi sistem pengendalian intern atas penerimaan retribusi parkir tepi jalan umum dan retribusi parkir khusus, adalah sebagai berikut:

1. Lingkungan Pengendalian. Prosedur penerimaan retribusi parkir telah mencerminkan adanya unsur pengendalian intern lingkungan pengendalian yaitu adanya pendelegasian wewenang dan tanggung jawab yang tepat. Hal ini jelas terlihat dari setiap pegawai yang diberi wewenang dalam melaksanakan prosedur penerimaan telah menjalankan pekerjaan sesuai dengan batasan tanggung jawabnya.

2. Penilaian Resiko. Berdasarkan wawancara yang dilakukan dengan pegawai unit pelaksana teknis perparkiran, yang melakukan pemungutan uang parkir terhadap pengguna layanan parkir yaitu petugas lapangan (buruh), kemudian yang melakukan penagihan terhadap pemungutan tersebut yaitu pegawai unit pelaksana teknis perparkiran dengan sistem bagi hasil. Hal ini rentan terjadi penyimpangan karena tidak adanya prosedur yang jelas terhadap bagi hasil tersebut. Jadi Penilaian resiko tersebut belum mencerminkan pengendalian intern yang baik.

3. Kegiatan Pengendalian. Prosedur penerimaan retribusi parkir telah mencerminkan adanya unsur pengendalian intern kegiatan pengendalian yaitu adanya pemisahan fungsi/pemisahan tugas yang cukup, pencatatan yang akurat dan tepat waktu atas transaksi dan kejadian.

4. Informasi dan Komunikasi. Prosedur penerimaan retribusi parkir telah mencerminkan adanya unsur pengendalian intern informasi dan komunkasi. Hal ini dapat dilihat dari dokumen yang digunakan dalam penerimaan retribusi yaitu surat tanda setoran dan surat tanda terima setoran PAD telah memuat informasi yang jelas dan handal kemudian telah dicatat dan dilaporkan oleh bendahara penerimaan kepada pimpinan dinas secara tepat waktu serta dilakukan secara terus menerus.

5. Pemantauan. Pemantauan pengendalian intern pada penerimaan retribusi parkir yaitu kepala dinas setiap bulan mengetahui dan menandatangani surat tanda setoran (STS) yang akan disetorkan ke bank (kas daerah) yang telah dibuat oleh bendahara penerimaan dan yang telah diverifikasi oleh kasubag keuangan.

Berdasarkan hal diatas maka sistem pengendalian intern pada prosedur penerimaan retribusi parkir belum mencerminkan sistem pengendalian intern yang memadai, karena belum adanya prosedur yang jelas terhadap sistem bagi hasil parkir tepi jalan umum oleh buruh dan penagih sehingga pencapaian realisasi retribusi parkir belum mencapai target.

Analisis Penerapan Sistem Pengendalian Intern atas Target dan Realisasi Penerimaan Retrubusi. Berdasarkan hasil penelitian diatas realisasi penerimaan retribusi yang dikelola Dinas Perhubungan Kota Manado diketahui realisasi penerimaan retribusi tahun 2016 yaitu Rp.2.611.918.900 atau melebihi target sebesar 102,85\% dan realisasi penerimaan retribusi tahun 2017 yaitu Rp. 2.695.192.100 atau mencapai target sebesar 
98,91\% . Penerimaan retribusi yang melebihi target antara lain Retribusi pengujian kendaraan bermotor sebesar 105,24\%, Retribusi Ijin Trayek sebesar 115,57\%, Retribusi Kepelabuhan sebesar 180,74\%. Sedangkan Realisasi penerimaan retribusi tahun 2017 sebesar Rp. 2.695.192.100 dibandingkan dengan Realisasi penerimaan retribusi tahun 2016 sebesar Rp. 2.611.918.900 mengalami peningkatan sebesar Rp. 83.373.200 atau sebesar 3.09\%. Namun realisasi penerimaan retribusi parkir tepi jalan umum dan retribusi parkir khusus belum mencapai target yang ditentukan. Dari hasil analisis tersebut menunjukkan bahwa realisasi penerimaan keseluruhan tahun 2016 melebihi target yaitu sebesar 102,85\% berada pada tingkat lebih dari 100\% maka dikategorikan "sangat efektif" dan Realisasi penerimaan keseluruhan tahun 2017 mencapai 98,91\% berada pada tingkat 90\% - 100\% maka dikategorikan "efektif". Namun Retribusi Parkir Tepi Jalan Umum Tahun 2016 dan 2017 berada pada tingkat "cukup efektif" karena hanya mencapai 80,41\% ditahun 2016 dan $82,22 \%$ ditahun 2017. Retribusi parkir khusus juga pada tahun 2016 dikategorikan kurang efektif karena hanya mencapai 75,45\% dan tahun 2017 mengalami penurunan sehingga dikategorikan "tidak efektif karena hanya mencapai 43,47\%.

\section{KESIMPULAN DAN SARAN}

\subsection{Kesimpulan}

Berdasarkan hasil penelitian dan pembahasan maka dapat disimpulkan sebagai berikut:

1. Penerapan sistem pengendalian atas kinerja Dinas Perhubungan Kota Manado dikategorikan cukup efektif karena telah mencapai $81,48 \%$ sesuai dengan Peraturan Pemerintah Nomor 60 Tahun 2008 tentang Sistem Pengendalian Intern Pemerintah.

2. Penerapan sistem pengendalian intern atas prosedur penerimaan retribusi parkir pada Dinas Perhubungan Kota Manado belum efektif karena belum adanya prosedur yang jelas terhadap sistem bagi hasil antara buruh parkir dan penagih sehingga rentan terjadi penyimpangan yang berindikasi penerimaan retribusi parkir tidak mencapai target.

3. Penerapan sistem pengendalian intern atas realisasi penerimaan retribusi tahun 2016 dikategorikan sangat efektif karena mencapai 102,85\% melebihi target yang ditentukan dan pada tahun 2017 realisasi penerimaan retribusi dikategorikan efektif karena mencapai $98,91 \%$. Namun terdapat kekurangan yaitu retribusi parkir tepi jalan umum dikategorikan kurang efektif dan retribusi parkir khusus dikategorikan tidak efektif dikarenakan jauh dari target yang ditentukan.

\subsection{Saran}

Berdasarkan hasil uraian pembahasan dan kesimpulan yang telah diuraikan diatas, maka saran yang dapat diberikan yaitu:

1. Dinas Perhubungan Kota Manado diharapkan bisa lebih meningkatkan dan mengoptimalkan lagi sistem pengendalian intern yang sudah ada, agar Dinas Perhubungan Kota Manado bisa memaksimalkan kinerja.

2. Diharapkan untuk Dinas Perhubungan Kota Manado membuat prosedur yang jelas terhadap sistem bagi hasil antara buruh dan penagih agar kecurangan - kecurangan yang terjadi terhadap penerimaan retribusi parkir dapat diminimalisir sehingga target yang ditentukan bisa tercapai di tahun - tahun berikutnya.

3. Saran untuk penelitian selanjutnya diharapkan agar dapat memperbaharui aturan-aturan dan literatur yang berlaku mengenai sistem pengendalian intern pemerintah. 


\section{DAFTAR PUSTAKA}

COSO, 2013. Internal Control - Integrated Framework : Executive Summary. Durham, North Carolina, May 2013.

Mahsun, Muhamad. 2014. Pengukuran Kinerja Sektor Publik. BPFE-Yogyakarta.

Mardiasmo. 2014. Akuntansi Sektor Publik, Andi, Yogyakarta

Nordiawan, Wiratna, 2012. Akuntansi sektor publik, pengertian akuntansi pemerintahan.

Pustaka baru press.

Peraturan Daerah Kota Manado Nomor 3 Tahun 2011 Tentang Retribusi Jasa Umum

Peraturan Daerah Kota Manado Nomor 4 Tahun 2011 Tentang Retribusi Jasa Usaha.

Peraturan Pemerintah Republik Indonesia Nomor 60 Tahun 2008 Tentang Sistem Pengendalian Intern Pemerintah

Siregar, 2015. Akuntansi Sektor Publik. Penerbit Unit Penerbit dan Percetakan Sekolah Tinggi Ilmu Manajemen YKPN Yogyakarta.

Sujarweni. 2015. Sistem Akuntansi. Cetakan Pertama. Penerbit Pustaka Baru Press. Yogyakarta.

Sudaryono, 2015. Metodologi Riset di Bidang TI (Panduan Praktis, Teori, dan Contoh Kasus). Penerbit CV.ANDI OFFSET Yogyakarta 